\title{
BENTUK DAN FUNGSI TULISAN TATO ARAB DI MEDIA SOSIAL
}

\author{
Abdul Jawat Nur \\ Universitas Gadjah Mada \\ Bulaksumur, Caturtunggal, Kec. Depok, Kabupaten Sleman, \\ Daerah Istimewa Yogyakarta 55281 \\ e-mail:jawatnur@ugm.ac.id
}

\begin{abstract}
Abstrack
This paper will describe the form of lingual units and the function of writing on Arabic tattoos on social media. The phenomenon of Arabic tattoo writing is interesting to study because based on the data found, it is known that there are various types of Arabic tattoo writing, such as words, phrases, and sentences. In addition, it was also found the function of Arabic tattoo writing on social media, including the form of self-expression or group expression. This research was carried out through three strategic stages, namely: the stage of data provision, data analysis, and presentation of the results of data analysis. Based on the research that has been done, it is concluded that on social media found Arabic tattoo writing in the form of words, phrases, and sentences. When viewed from the function of the language, Arabic tattoo writing has the functions of (1) fatigue, (2) referential, and (3) imaginative.
\end{abstract}

Keywords: Writing, Arabic Tattoo, Lingual Unit Form, Language Function

\begin{abstract}
Abstrak
Tulisan ini akan mendeskripsikan bentuk satuan lingual dan fungsi tulisan pada tato Arab di media sosial. Fenomena tulisan tato Arab ini menarik unutk dikaji karena berdasarkan data yang ditemukan, diketahui bahwa jenis tulisan tato Arab ada bermacam-macam, seperti: kata, frasa, dan kalimat. Di samping itu, ditemukan pula fungsi tulisan tato Arab di media sosial, di antaranya adalah sebagai bentuk ekspresi identitas diri atau kelompok. Penelitian ini dilaksanakan melalui tiga tahapan yang strategis, yaitu: tahap penyediaan data, analisis data, dan
\end{abstract}


penyajian hasil analisis data. Berdasarkan penelitian yang telah dilakukan disimpulkan bahwa di media sosial ditemukan tulisan tato Arab yang berbentuk kata, frasa, dan kalimat. Bila dilihat dari fungsi bahasanya, tulisan tato Arab mempunyai fungsi (1) fatik, (2) referensial, dan (3) denotatif.

Kata Kunci: Tulisan, Tato Arab, Bentuk Satuan Lingual, Fungsi Bahasa

\section{A. Pendahuluan}

Sampai saat ini, bahasa menjadi objek kajian yang menarik karena perannya dalam menangkap luasnya pemikiran dan usaha manusia. ${ }^{1}$ Pemikiran-pemikiran manusia tersebut diungkapkan melalui bahasa, baik lisan maupun tulisan. Salah satu bentuk ekspresi manusia dalam bahasa tulis adalah melalui tato yang sering digambarkan atau dituliskan pada anggota tubuh. Dalam Kamus Besar Bahasa Indonesia disebutkan, tato adalah gambar (lukisan) pada kulit tubuh. ${ }^{2}$ Dengan demikian, menato berarti melukis atau menulis pada kulit tubuh dengan cara menusuki kulit dengan jarum halus kemudian memasukkan zat warna ke dalam bekas tusukan itu. Gambaran atau lukisan tato pada anggota tubuh secara umum dikenal dua macam tato, yaitu tato permanen dan tato temporer. ${ }^{3}$ Tato permanen tidak bisa hilang dari anggota tubuh, sedangkan tato temporer mudah sekali hilang dan tidak membekas pada anggota tubuh.

Fenomena tato ini menarik untuk diteliti karena seni menato ini hampir ditemui di seluruh penjuru dunia. Bila diamati dengan saksama, hiasan tato pada tubuh bermacam-macam ragamnya, seperti gambar pemandangan alam,

\footnotetext{
${ }^{1}$ David Crystal, The Cambridge Encyclopedia of Language (New York: Cambridge University Press, 1992), h. 13.

2 "Arti kata tato - Kamus Besar Bahasa Indonesia (KBBI) Online," diakses 16 Mei 2019, https://kbbi.web.id/tato.

3 "Tato Temporer Justru Lebih Rentan Alergi," diakses 16 Mei 2019, https://hot.detik.com/art/d-2401868/tato-temporer-justru-lebih-rentan-alergi.
} 
gambar orang, binatang, simbol tertentu, rajah atau jimat, dan ada pula yang berupa tulisan, termasuk tulisan Arab.

Seni tato bertuliskan huruf Arab pada anggota tubuh juga diminati oleh kalangan masyarakat, baik masyarakat Arab maupun non-Arab. Hal ini seperti tulisan-tulisan tato Arab pada anggota tubuh yang mereka pertontonkan di media sosial. Yang menarik dari tato tersebut adalah adanya gambar, tulisan, atau kombinasi keduanya. Berkaitan dengan tato yang berupa tulisan Arab atau kombinasi tulisan Arab dan gambar ini menarik untuk dikaji lebih dalam lagi karena tulisan-tulisan Arab yang ditato di tubuh berupa satuan lingual dan tentunya mempunyai fungsi kebahasaan tertentu. Sebagai contoh dapat diberikan, salah satunya seperti pada contoh gambar (1) berikut ini.

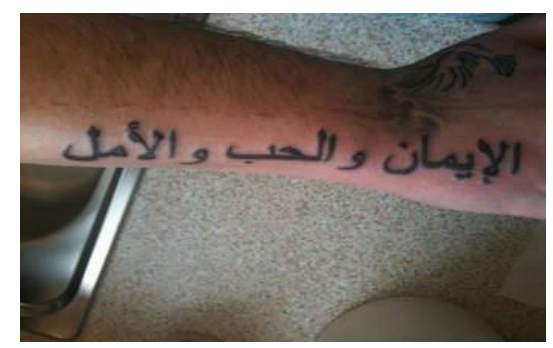

Gambar 1

Sumber: http://www.checkoutmyink.com/tattoos/walby1984/faith-hope-love-in-arabic-writing/

Pada contoh tato pada gambar (1) tersebut terlihat seorang laki-laki yang menato tangannya dengan tulisan Arab dan di atas tulisan tersebut dihiasi dengan lukisan tumbuhan yang distilirisasi:

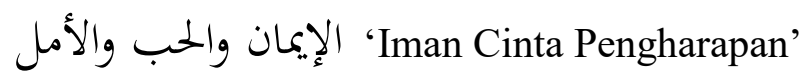

Tulisan tato Arab tersebut merupakan ekspresi seseorang untuk menyatakan keyakinannya bahwa kehidupan ini harus dijalani dengan iman kepada Tuhan, cinta kasih yang nyata kepada sesama, dan harapan yang selalu hidup dan kuat. ${ }^{4}$

4 "Meningkatkan Iman, Harapan dan Cinta Kepada Tuhan (Siraman Rohani, Senin 28/11/2016) - Mirifica News," diakses 16 Mei 2019, 
Berdasarkan latar belakang tersebut, maka permasalahan yang akan dibahas dalam tulisan ini adalah jenis satuan lingual apa saja yang digunakan dalam menuliskan tato Arab yang ditemukan dalam media sosial, dan apa fungsinya ditinjau dari kajian sosiolinguistik. Di samping itu, penelitian ini juga akan mendeskripsikan budaya yang melingkupi penatoan tulisan Arab pada anggota tubuh.

Penelitian ini difokuskan pada bentuk dan fungsi tato tulisan Arab di media sosial. Oleh karena itu, paradigma keilmuan dalam penelitian ini berkaitan dengan bentuk satuan lingual dan fungsi bahasa, seperti yang akan dijelaskan pada bagian berikut ini.

\section{Satuan Lingual}

Satuan lingual yang akan dijelaskan dalam paradigma keilmuan ini adalah kata, frasa, dan kalimat.

\section{a. Kata (al-kalimah)}

Secara gramatikal kata atau al-kalimah merupakan satuan terbesar dalam tataran morfologi dan sebagai satuan terkecil dalam tataran sintaksis. 5 Dalam bahasa Arab, kata dibagi menjadi tiga, yaitu ism (nomina), fi'l (verba), dan harf (partikel). Menurut al-Galayaini, ism adalah setiap kata yang menunjukkan arti manusia, hewan, tumbuhan, benda, tempat, waktu, sifat, atau arti kata kerja yang tidak terkait dengan waktu, misalnya: Khalid 'nama orang', farasun 'kuda', 'usfur 'burungburung', dar 'rumah, kampung', ma' 'air'. Kata kerja atau fi'l, menurut al-Galayaini, adalah kata (al-kalimah) yang menunjukkan terjadinya suatu perbuatan pada waktu tertentu, misalnya:, seperti: ja'a 'dia lakilaki sudah datang', yaji 'u 'dia laki-laki sedang datang', dan ji' $a$ 'dia lakilaki sudah didatangi'. Adapun harf (partikel) adalah kata yang

\footnotetext{
http://www.mirifica.net/2016/11/27/meningkatkan-iman-harapan-dan-cinta-kepadatuhan-siraman-rohani-senin-28112016/.

${ }^{5}$ Abdul Chaer, Sintaksis Bahasa Indonesia Pendekatan Proses (Jakarta: Rineka Cipta, 2009), h. 37.
} 
maknanya sempurna bila bergabung dengan kata yang lain, seperti: hal 'apakah', fi 'di dalam', lam 'belum', 'ala 'di atas', inna 'sesungguhnya', $\min$ 'dari'. 6

\section{b. Frasa (al-murakkab)}

Frasa dibentuk dari dua buah kata atau lebih dan mengisi salah satu fungsi sintaksis. ${ }^{7}$ Istilah frasa dalam bahasa Arab hampir mirip dengan al-murakkab. Al-Galayaini menjelaskan bahwa frasa atau al-murakkab adalah ujaran yang terdiri dari dua kata atau lebih, seperti pada contoh (1), (2), dan (3) berikut:

$$
\text { النجاة في الصدق }
$$

'keselamatan dalam kejujuran',

(2)

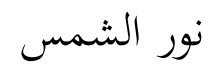

'cahaya matahari'

$$
\text { الإنسانية الفضيلة }
$$

'kemanusiaan yang utama'.

Lebih jauh al-Galayaini menjelaskan bahwa al-murakkab dalam bahasa Arab dibagi menjadi enam, yaitu isnadi, idafi, bayani, 'atfi, mazji, dan 'adadi. Al-Murakkab al-isnadi atau disebut juga dengan jumlah atau kalimat adalah susunan kalimat yang terdiri dari musnad dan musnad ilaih. ${ }^{8}$ Seperti dalam contoh (4) berikut:

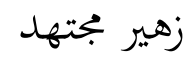

'Zuhair adalah orang yang serius'.

\footnotetext{
${ }^{6}$ Lebih lanjut lihat Anton Ad-Dahdah, A Dictionary of Arabic Grammar in Charts
} and Tables (Bairut: Maktabah Lubnan Nasyirun, 2001), h. 3; Lihat juga Syaikh Mustafa AlGalayaini, Jami'u ad-Durusi al-'Arabiyyati Mausu'atun Fi Salasati Ajza' (Bairut: Dar al-Hadis, 2005), h. 9-11.

${ }^{7}$ Chaer, Sintaksis Bahasa Indonesia Pendekatan Proses, h. 39.

${ }^{8}$ Al-Galayaini, Jami'u ad-Durusi al-'Arabiyyati Mausu'atun Fi Salasati Ajza,' h. 11. 
Pada contoh (4), Zuhair sebagai musnad ilaih (subjek) dan mujtahidun sebagai musnad (predikat). Hal ini merupakan perbedaan yang mendasar. Frasa dibentuk dari gabungan/ kesatuan kata yang terbentuk dari dua kelompok kata atau lebih yang memiliki satu makna gramatikal (makna yang berubah menyesuaikan dengan konteks). Dengan kata lain, frasa ialah gabungan dari dua kata atau lebih, namun tidak dapat membentuk kalimat sempurna sebab tidak memiliki predikat. ${ }^{9}$ Berbeda dengan al-murakkab al-isnadi yang merupakan gabungan dua kata, namun sudah punya predikat, seperti contoh (4).

Al-Murakkab al-idafa adalah kelompok kata yang terdiri dari mudaf dan mudaf ilaih. Seperti: kitabu at-tilmiz 'buku milik murid', khatamu fiddatin 'cincin dari perak', dan saumu an-nahari 'puasa di siang hari'.

Al-Murakkab al-'atfi, yaitu kelompok kata yang tersusun dari ma'tuf dan ma'tuf 'alaih dengan perantaraan harf al-'atf di antara keduanya. Sebagai contoh dapat diberikan, misalnya: yanalu at-tilmizu wa at-tilmizatu al-hamda 'Siswa dan siswi itu menerima pujian'.

Al-Murakkab al-majzi, yaitu setiap dua kata yang dibentuk menjadi satu kata. Contoh frasa tersebut adalah Ba'labak 'nama kota di Suriah', Hadramaut 'nama kota di Yaman', Sibawaih 'nama tokoh linguis Arab'.

Al-Murakkab al-'adadi merupakan bagian dari frasa atau almurakkab al-majzi, yaitu setiap dua bilangan yang di antara keduanya harf 'atf diperkirakan. Frasa ini adalah bilangan dari ahada 'asyara 'sebelas' sampai tis'ata asyrata 'sembilan belas', dan dari al-hadiyata 'asyara 'kesebelas' sampai at-tasi'ta 'asyara 'kesembilan belas'. ${ }^{10}$

9 “Pengertian Frasa, Ciri-ciri, Jenis Dan Contoh Frasa," Materi Belajar (blog), diakses 16 Mei 2019, http://materi4belajar.blogspot.com/2016/02/pengertian-frasa-cirijenis-dan-contoh.html.

${ }^{10}$ Al-Galayaini, Jami'u ad-Durusi al-'Arabiyyati Mausu'atun Fi Salasati Ajza,' h. 1314. 


\section{c. Kalimat (Al-Jumlah)}

Kalimat dalam bahasa Arab disebut dengan jumlah. Wahbah menyatakan bahwa kalimat adalah satuan lingual yang mempunyai arti yang sempurna dan ketika diucapkan terdiri dari subjek dan predikat. Contohnya adalah seperti: Asy-Syamsu thali'atun 'Matahari terbit'. Dalam contoh ini, asy-syamsu sebagai maudu'/ musnad ilaih (subjek) dan thali'atun sebagai mahmul/ musnad (predikat). ${ }^{11}$ Sementara itu Chaer mendefinisikan kalimat sebagai satuan sintaksis yang disusun dari konstituen dasar yang biasanya berupa klausa, dilengkapi dengan konjungsi bila diperlukan, serta diakhiri dengan intonasi final. ${ }^{12}$

Kalimat, menurut para ahli bahasa Arab, dibagi menjadi dua, jumlah fi'liyyah (verbal sentence) dan jumlah ismiyyah (nominal sentence). ${ }^{13}$ Jumlah fi'liyyah yaitu kalimat yang diawali dengan kata kerja, contoh: Bana al-Qahirata Jauharu as-Saqilli 'Jauhar as-Saqilli telah membangun Kairo'. Jumlah ismiyyah yaitu kalimat yang diawali dengan kata benda, contoh: As-sama'u safiyyatun 'Langit itu cerah'.

\section{Fungsi Bahasa}

Beberapa ahli bahasa telah menyampaikan pemikirannya tentang fungsi bahasa, di antaranya adalah Chaer (2014) dan Crystal (2015). Berdasarkan kedua pendapat tersebut dapatlah dirumuskan bahwa fungsi bahasa secara sosiolinguistis bisa dilihat dari sudut penutur, pendengar, topik, kode, dan amanat pembicaraan.

Dilihat dari segi penutur, bahasa mempunyai fungsi personal atau pribadi, ada juga yang menyebut fungsi emotif. ${ }^{14}$ Hal ini berarti bahwa

\footnotetext{
${ }^{11}$ Majdi Wahbah, Mu'jamu al-Mustalahat al-'Arabiyyah Fi al-Lugah wa al-Adab (Beirut: Maktabah Lubnan, 1984), h. 137.

${ }^{12}$ Chaer, Sintaksis Bahasa Indonesia Pendekatan Proses, h. 44.

${ }^{13}$ Wahbah, Mu'jamu al-Mustalahat al-'Arabiyyah Fi al-Lugah wa al-Adab, h. 137.

${ }^{14}$ Abdul Chaer dan Leonie Agustina, Sosiolinguistik Pengenalan Awal (Jakarta: Rineka Cipta, 2004), h. 15.
} 
ketika seorang penutur menuturkan apa yang ingin dia tuturkan ke mitra wicara, dia juga menyatakan sikap terhadap apa yang dituturkannya itu. Penutur bukan hanya mengungkapkan emosi lewat bahasa, tetapi juga memperlihatkan emosi ke mitra wicara ketika menuturkannya, sehingga dia dapat diketahui apakah dalam keadaan marah, sedih, atau senang.

Dilihat dari sudut pendengar, bahasa berfungsi direktif (instrumental), artinya mengatur tingkah laku pendengar. ${ }^{15}$ Hal ini berarti dalam bertutur, pendengar tidak hanya melakukan sesuatu, tetapi juga melakukan kegiatan yang sesuai dengan kemauan pembicara.

Dilihat dari kontak antara penutur dan pendengar bahasa berfungsi fatik (interpersonal/interaksional). ${ }^{16}$ Hal ini berarti bahasa berfungsi menjalin dan memelihara hubungan, memperlihatkan perasaan persaudaraan atau solidaritas sosial, seperti sapaan, dan basa basi. ${ }^{17}$

Dilihat dari topik ujaran, bahasa berfungsi referensial, ada juga yang menyatakan fungsi representasional, kognitif, denotatif, dan informatif, bahasa berfungsi sebagai alat untuk membicarakan objek atau peristiwa yang ada di sekeliling penutur atau yang ada dalam budaya pada umumnya. ${ }^{18}$ Fungsi ini melahirkan paham tradisional yang menyatakan bahwa bahasa sebagai alat untuk menyatakan pikiran. Cyrstal menambahkan bahwa fungsi ini diwakili oleh semua jenis pencatatan, seperti pencatatan sejarah, survei geografis, perhitungan bisnis, laporan ilmiah, rapat parlemen, dan data umum. ${ }^{19}$

Dilihat dari kode yang digunakan bahasa berfungsi metalingual atau metalinguistik. ${ }^{20}$ Fungsi bahasa ini berarti bahwa bahasa itu digunakan

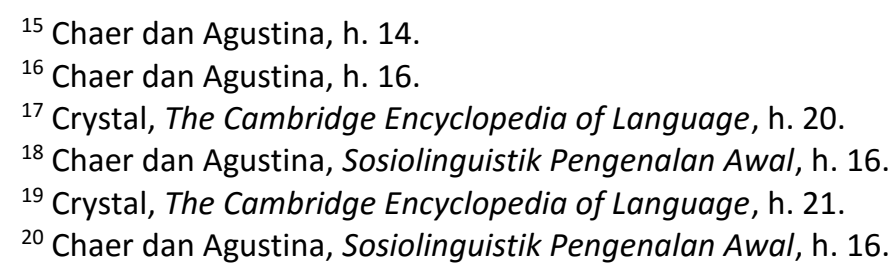

${ }^{20}$ Chaer dan Agustina, Sosiolinguistik Pengenalan Awal, h. 16. 
untuk membicarakan bahasa itu sendiri, seperti dalam proses pembelajaran bahasa yang menjelaskan kaidah-kaidah bahasa dan juga dalam kamus monolingual.

Dilihat dari segi amanat yang akan disampaikan, bahasa itu berfungsi imajinatif (poetic speech) ${ }^{21} \mathrm{Hal}$ ini berarti bahwa bahasa dapat digunakan untuk menyampaikan pikiran, gagasan, dan perasaan, baik yang sebenarnya maupun yang hanya imajinasi, seperti dalam puisi, cerita, dongeng, lelucon, dan sebagainya.

\section{B. Pembahasan}

\section{a. Bentuk Satuan Lingual Tato Tulisan Arab}

Berdasarkan analisis bentuk satuan lingual tulisan pada tato Arab di media sosial yang telah dilakukan, dapat diketahui bahwa tulisan tato Arab di media sosial berbentuk kata (al-kalimat), frasa (al-murakkab), dan kalimat (al-jumlah) seperti yang diuraikan dalam bagian berikut.

\section{Tulisan Tato Arab Berbentuk Kata (al-kalimah)}

Berdasarkan studi kepustakaan, banyak sekali ditemukan definisi tentang kata. Salah satunya mengatakan bahwa kata adalah satuan bahasa yang dapat berdiri sendiri, terjadi dari morfem tunggal, misalnya: batu, rumah, datang atau gabungan morfem, misalnya: pejuang, mengikuti, mahakuasa dan lain-lain. ${ }^{22}$ Dalam bahasa Arab, kata dibagi menjadi tiga, yaitu: ism (nomina), fi'l (verba), dan harf (partikel). ${ }^{23}$

\footnotetext{
${ }^{21}$ Chaer dan Agustina, h. 17.

${ }^{22}$ W.S. Hasanudin, Ensiklopedi Kebahasaan Indonesia (Bandung: Penerbit Angkasa, 2014), h. 574.

${ }^{23}$ Abdul Gani dan Aiman Amin, Mulakhkhas Qawa'id al-Lugah al-'Arabiyyah (Kairo: Dar at-Taufiq li at-Turas, 2012), h. 13.
} 
Tulisan tato Arab berupa kata yang ditemukan di media massa adalah kata benda, yaitu kata benda maskulin (ism muzakkar) dan kata benda feminin (ism mu'annas), seperti pada gambar (2) berikut.

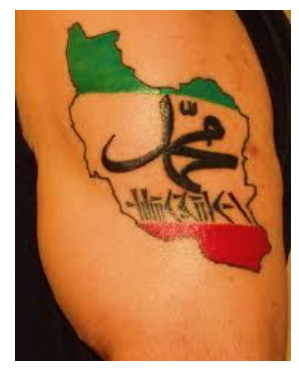

Gambar 2

Sumber: http://www.tattoodesigns24.com/map-tattoos/arabic-map-tattoo-on-shoulder/

Pada gambar (2) tersebut tampak seorang laki-laki yang menatokan nama diri Muhammad dalam gambar sebuah peta yang di bawah tulisan tato Muhammad tersebut terdapat tulisan beraksara China di lengan kanannya. Kata Muhammad merupakan kata benda (ism) yang menunjukkan nama diri seseorang. Dalam bahasa Arab, kata Muhammad tergolong kata benda yang menunjukkan jenis maskulin (muzakkar). ${ }^{24}$

Di samping itu, bila dilihat dari segi keta'rifannya, kata benda tulisan pada tato Arab yang ditatokan pada anggota tubuh dibagi menjadi dua, yaitu ism ma'rifat (kata benda defenit) dan ism nakirah (kata benda indefenit), seperti pada gambar (3) berikut.

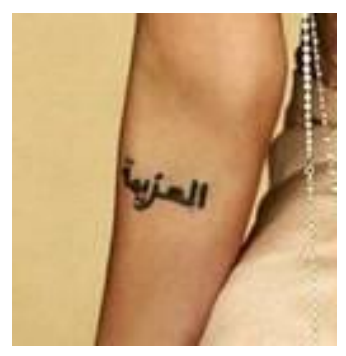

Gambar 3

Sumber: http://www.freetattoodesigns.org/angelina-jolie-tattoos.htm/

${ }^{24}$ Al-Galayaini, Jami'u ad-Durusi al-'Arabiyyati Mausu'atun Fi Salasati Ajza,' h. 80. 
Tato tulisan Arab pada data (3) tersebut merupakan tato yang dimiliki oleh seorang artis dunia yang terkenal, yaitu Angelina Jolie yang menatokan kata al-'azimah di tangan kanannya. Dalam bahasa Arab al-'azimah yang berarti 'kemauan yang teguh, tekat, kuat, kekuasaan'. ${ }^{25}$ Kata al-'azimah tergolong kata benda jenis feminin karena menunjukkan jenis perempuan. ${ }^{26}$ Kata al- 'azimah termasuk kata benda defenit karena kata tersebut didahului oleh partikel al (ال).

Asumsi Angelina Jolie menatokan tulisan Arab al-'azimah (kemauan yang kuat, teguh, tegar) adalah seperti yang diberitakan di beberapa media bahwa aktris Angelina Jolie tersebut telah mengungkapkan beban berat hidupnya kepada majalah Vanity Fair. Jolie mengungkapkan beratnya proses yang harus dilalui untuk bangkit setelah perceraian dan berjuang melawan penyakitnya. Aktris yang pernah meraih piala Oscar tersebut harus menghadapi kenyataan bahwa otot di salah satu sisi wajahnya melemah akibat Bell's Palsy. Sementara itu, dia juga sedang mengalami hipertensi. Sebagai akibat penyakit yang dideritanya tersebut, Angelina Jolie, yang mempunyai enam anak itu harus menjalani berbagai pengobatan dan akupuntur. Tindakan itu menyebabkan kulitnya menjadi sangat kering dan beberapa helai rambutnya berubah warna jadi sangat abu-abu. ${ }^{28}$

\section{Tulisan Tato Arab Berbentuk Frasa (al-Murakkab)}

Frasa adalah satuan gramatikal yang terdiri dari dua kata atau lebih yang tidak melampaui batas fungsi unsur klausa atau sifatnya tidak

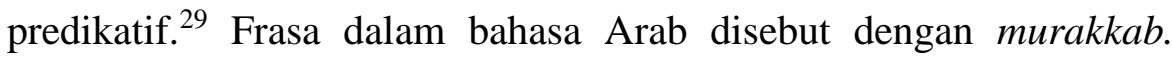

\footnotetext{
${ }^{25}$ A.W. Munawwir, Al-Munawwir: Kamus Arab-Indonesia (Surabaya: Pustaka Progressif, 2002), h. 928.

${ }^{26}$ Al-Galayaini, Jami'u ad-Durusi al-'Arabiyyati Mausu'atun Fi Salasati Ajza,' h. 81.

${ }^{27}$ Al-Galayaini, h. 118.

28 "Curhat Angelina Jolie Soal Penyakit dan Perceraiannya | Republika Online," diakses 17 Mei 2019, https://www.republika.co.id/berita/\%20senggang\%20/blitz/17/07/27/otq7r4328-curhatangelina-jolie-soal-penyakit-dan-perceraiannya.

${ }^{29}$ Hasanudin, Ensiklopedi Kebahasaan Indonesia, h. 381.
} 
Berdasarkan data yang telah dikumpulkan serta diklasifikasikan, tulisan tato Arab yang berbentuk frasa (murakkab) di media sosial yaitu murakkab wasfi (frasa endosentrik atributif), murakkab idafi (frasa endosentrik apositif), dan murakkab 'atfi (frasa endosentrik koordinatif). Penjelasannya akan diuraikan pada bagian berikut ini.

a) Murakkab Wasfi (frasa endosentrik atributif)

Murakkab Wasfi adalah susunan frasa yang terdiri dari kata sifat dan kata yang disifatinya. ${ }^{30}$ Tato Arab yang tergolong murakkab wasfi di media sosial yaitu pada gambar (4) berikut:

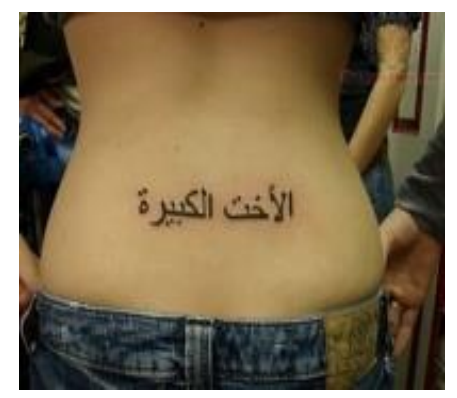

Gambar 4

Sumber: http://tattoo.wf/tattoo/13488-elegant-thin-dark-black-arabic-tattoo-on-womans-lower-back/

Gambar (4) menunjukkan seorang wanita yang menatokan tulisan Arab di punggungnya, berbentuk frasa atau murakkab wasfi bertuliskan al-ukhtu al-kabirah yang berarti 'saudara perempuan yang besar'. Frasa tersebut terdiri dari dua kata, yaitu al-ukhtu 'saudara perempuan' dan al-kabirah 'besar'. Al-ukhtu adalah kata yang disifati (mausuf) berjenis feminin, tunggal dan al-kabirah adalah sifah berjenis feminin, tunggal. Konstruksi frasa/ murakkab wasfi harus memenuhi kriteria bahwa antara sifah dan mausuf-nya harus punya kesesuaian dalam hal jenis (maskulin atau feminin) dan jumlah (tunggal, dual, plural)-nya. ${ }^{31}$

${ }^{30}$ Al-Galayaini, Jami'u ad-Durusi al-'Arabiyyati Mausu'atun Fi Salasati Ajza,' h. 13.

${ }^{31}$ Al-Galayaini, h. 13. 
b) Murakkab Idafi (Frasa Endosentrik Apositif)

Murakkab idafi adalah frasa yang tersusun dari mudaf dan mudaf ilaih. ${ }^{32}$ Tulisan tato Arab berbentuk frasa atau murakkab idafi yang ada di media sosial yaitu seperti gambar (5) berikut.

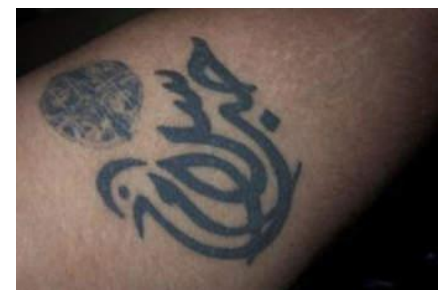

Gambar 5 - Sumber: http://www.checkoutmyink.com/tattoos/apuzilla/salaam-and-houb

Pada gambar (5) merupakan tulisan tato Arab yang berbentuk frasa atau murakkab idafi. Dalam data tersebut tampak seseorang yang menato tulisan Arab di tangan kanannya dengan motif burung merpati. Tulisan Arab pada tato tersebut terbaca hubbu as-salam yang berarti 'cinta kedamaian'. Dalam konteks ini, hubbu sebagai mudaf dan as-salam sebagai mudaf ilaih.

Tulisan tato Arab hubbu as-salam yang berbentuk burung merpati ini sejalan dengan simbol burung merpati. Burung merpati menjadi simbol perdamaian dan umur panjang sejak jaman Cina kuno. Demikian juga orang Mesir memakai burung merpati sebagai tanda ketenangan. ${ }^{33}$

c) Al-Murakkab al-Atfi (Frasa Endosentrik Koordinatif)

Al-murakkab al-'atfi adalah konstruksi frasa yang terdiri dari al-ma'tuf dan al-ma'tuf 'alaih dengan perantaraan partikel 'atf. ${ }^{34}$ Al-murakkab al-'atfi dalam tato Arab yang ditemukan pada media sosial adalah seperti pada gambar (6) berikut.

\footnotetext{
${ }^{32}$ Al-Galayaini, h. 13.
}

33 “Mengapa Burung Merpati Jadi Simbol Perdamaian?," diakses 17 Mei 2019, http://www.apakabardunia.com/2013/01/mengapa-burung-merpati-jadi-simbol.html.

${ }^{34}$ Al-Galayaini, Jami'u ad-Durusi al-'Arabiyyati Mausu'atun Fi Salasati Ajza,' h. 14. 


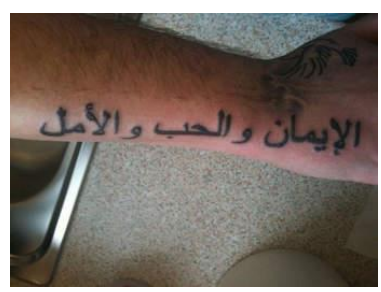

Gambar 6

Sumber: http://www.checkoutmyink.com/tattoos/walby1984/faith-hope-love-in-arabic-writing

Gambar (6) merupakan data yang memuat frasa atau murakkab atfi. Pada gambar (6) terlihat seseorang yang menato tangannya dengan tulisan Arab الإيمان و الحب و الأمل /al-imanu wa al-hubbu wa alamal/ 'Iman, Cinta, dan Pengharapan'. Konstruksi frasa al-imanu wa al-hubbu wa al-amal terdiri dari unsur-unsur yang setara dan secara eksplisit dihubungkan dengan partikel wa 'dan'. Al-imanu merupakan ma'tuf' alaih, wa sebagai partikel 'atf, al-hubbu sebagai 'atf, wa sebagai partikel 'atf, dan al-amal sebagai 'atf.

\section{Tulisan Tato Arab Berbentuk Kalimat (al-Jumlah)}

Tulisan tato Arab di media sosial yang berbentuk kalimat (jumlah) ada dua, yaitu jumlah ismiyyah dan jumlah fi'liyyah. Adapun penjelasan dari kedua jenis kalimat tersebut akan diuraikan pada bagian berikut ini.

a) Al-Jumlah al-Ismiyyah

Al-jumlah al-ismiyyah adalah kalimat yang diawali dengan kata benda yang disebut dengan mubtada' atau Subjek. ${ }^{35} \mathrm{Al}$-jumlah al-ismiyyah bisa disejajarkan dengan kalimat nominal. ${ }^{36}$ Tulisan tato Arab yang berbentuk al-jumlah al-ismiyyah di media sosial adalah seperti pada gambar (7) berikut.

${ }^{35}$ Ad-Dahdah, A Dictionary of Arabic Grammar in Charts and Tables, h. 1530.

36 "Penjelasan Kalimat Verbal dan Kalimat Nominal," diakses 17 Mei 2019, https://ketikakuberkata.blogspot.com/2018/01/penjelasan-kalimat-verbal-dankalimat.html. 


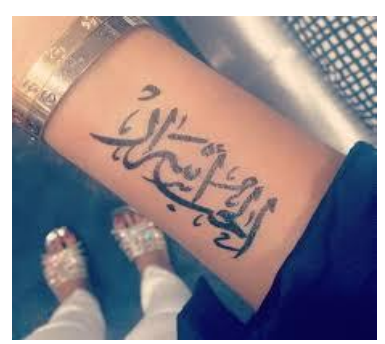

Gambar 7 - Sumber: https://id.pinterest.com/pin/461689399273261952/?/p=true

Pada gambar (7) tersebut tampak seorang gadis yang menatokan tulisan Arab di tangannya الحب أسرار/al-hubbu asrar/ 'Cinta itu misteri'. Al-hubbu asrar merupakan jumlah ismiyyah. Jumlah ismiyyah adalah kalimat yang diawali dengan kata benda. ${ }^{37}$ Kalimat tersebut Al-hubbu sebagai mubtada' yang setara dengan subjek dan asrar sebagai khabar yang setara dengan predikat.

b) Al-Jumlah al-Fi'liyyah

Al-Jumlah al-fi'liyyah adalah kalimat yang diawali dengan kata kerja. ${ }^{38}$ Al-Jumlah al-fi'liyyah berbeda dengan kalimat verbal dalam bahasa Indonesia, karena penyebutan Al-Jumlah al-fi'liyyah lebih terfokus pada awal kalimatnya yang berupa verba. Adapun kalimat verbal lebih terfokus pada predikat kalimatnya yang berupa verba. Bentuk tulisan tato Arab yang termasuk al-jumlah al-fi'liyyah di media sosial adalah seperti pada gambar (8) berikut ini.

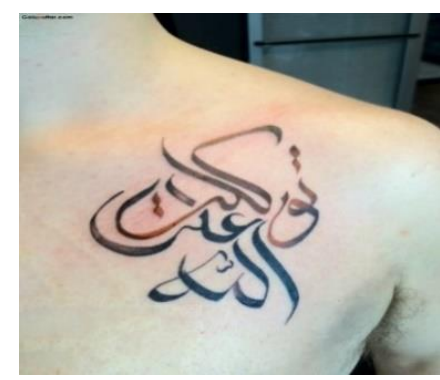

Gambar 8 -

Sumber: https://kaligrafi-islam.blogspot.com/2017/01/josh-berer-dari-corat-coret-graffity.html

${ }^{37}$ Ad-Dahdah, A Dictionary of Arabic Grammar in Charts and Tables, h. 15.

${ }^{38}$ Ad-Dahdah, h. 15. 
Pada gambar (8) tampak seorang laki-laki yang menatokan tulisan Arab توكلت على الله /tawakkaltu 'ala Allah/ 'Aku patuh kepada Allah'. Kalimat Tawakkaltu 'ala Allah merupakan jumlah fi'liyyah karena kalimat tersebut diawali dengan verba tawakkaltu 'Aku (telah) patuh' yang merupakan verba perfektum yang bersambung dengan kata ganti personal $t u$ 'saya', dan 'ala Allah merupakan frasa preposisional.

\section{Tulisan Tato Arab yang Berbentuk Rajah}

Selanjutnya, di media sosial juga ditemukan tulisan tato Arab yang disebut dengan rajah. Rajah, mengandung tiga pengertian, yaitu: (1) suratan (gambaran, tanda, dsb.) yang dipakai sebagai azimat (untuk penolak penyakit dsb.), (2) garis pada tapak tangan; guratan tangan; retak tangan, dan (3) coreng-coreng (cacahan) pada tubuh yang dibuat dengan barang tajam; tato. ${ }^{39}$ Dalam konteks penelitian ini, yang sesuai dengan definisi tersebut adalah definisi yang pertama dan ketiga.

Adapun tulisan tato Arab di media sosial yang berbentuk rajah adalah seperti pada gambar (9) berikut.

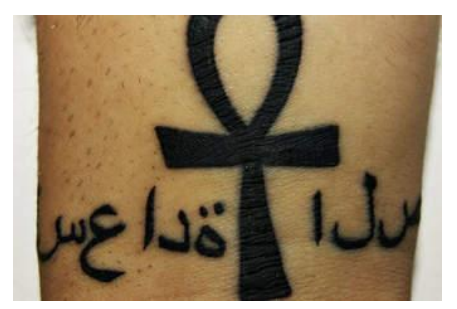

Gambar 9 - Sumber: https://www.deviantart.com/wtflopes/art/Ansata-Cross-Tatto-212846566

Gambar (9) merupakan tato tulisan Arab yang berupa rajah. Rajah tersebut ditulis di tangan seseorang dengan tulisan Arab yang dipisahpisah, yaitu o da da dengah tulisan tersebut ada simbol tulisan Mesir Kuno yang disebut dengan Ankh. Tulisan Arab tersebut tidak

39 "Rajah - Wiktionary bahasa Indonesia," diakses 17 Mei 2019, https://id.wiktionary.org/wiki/rajah. 
ditulis dari kanan ke kiri, namun dari kiri ke kanan. Jika tulisan tersebut dibaca dari kiri ke kanan tertulis sa'adah yang berarti 'bahagia'.

Menurut situs www.tattoo.com, Ankh adalah simbol agama penting dalam masyarakat Mesir Kuno dan berarti "kehidupan". Ankh adalah gabungan dari dua simbol; salib dan lingkaran. Banyak orang berteori bahwa itu adalah penggambaran matahari terbit atau terbenam. Sementara itu ada pendapat yang lain mengatakan bahwa Ankh adalah simbol kesuburan yang menggabungkan gambar lingga dan rahim untuk mewakili siklus yang sedang berlangsung. Di samping itu, simbol Ankh yang "salib dengan pegangan", adalah simbol kunci kehidupan jiwa yang kekal. ${ }^{40}$

Dengan demikian dapatlah dikatakan bahwa gambar (9) merupakan kombinasi tulisan Arab dengan simbol kepercayaan Mesir Kuno. Orang yang memakai rajah tulisan tato Arab sa'adah dan simbol tulisan Mesir Kuno Ankh mengharapkan kehidupan yang abadi, baik dunia maupun ketika dia sudah meninggal.

\section{Tulisan Tato Arab dari Ayat suci}

Berdasarkan data yang telah dikumpulkan, tulisan tato Arab di media sosial diklasifikasikan menjadi dua macam, yaitu dari kitab suci Alquran dan Injil. Seperti gambar (10) berikut.

a) Tulisan tato Arab dari Al-Qur'an

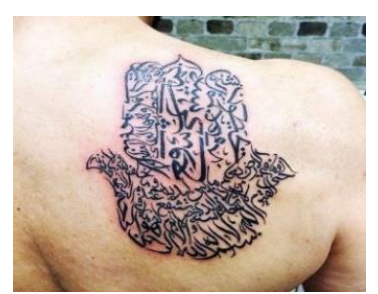

Gambar 10 - Sumber: https://bodyartguru.com/amazing-arabic-tattoo-designs/

40 "Mengenal Makna Dari Berbagai Simbol Agama," diakses 17 Mei 2019, http://www.martinrecords.com/pengetahuan/mengenal-makna-dari-berbagai-simbolagama/. 
Pada gambar (10) merupakan tulisan tato Arab ditatokan pada bahu kanan seorang laki-laki dengan tulisan tato Arab dari bawah ke atas merupakan salah satu ayat dari surat al-Baqarah ayat 255 yang lebih dikenal dengan ayat al-Kursi yang ditulis dalam simbol hamsa atau disebut juga sebagai Tangan Fatima. Hamsa adalah simbol religius yang dirancang untuk menangkal kejahatan.

Disebutkan bahwa simbol hamsa tampak seperti tangan kanan yang diperluas dengan mata di tengah telapak tangan. Simbol hamsa membawa banyak makna, termasuk perlindungan terhadap kejahatan, membuktikan bahwa Tuhan ada dalam segala hal dan juga kekuatan untuk orang lemah dan perlindungan selama kehamilan.

b) Tulisan Tato Arab dari Kitab Injil

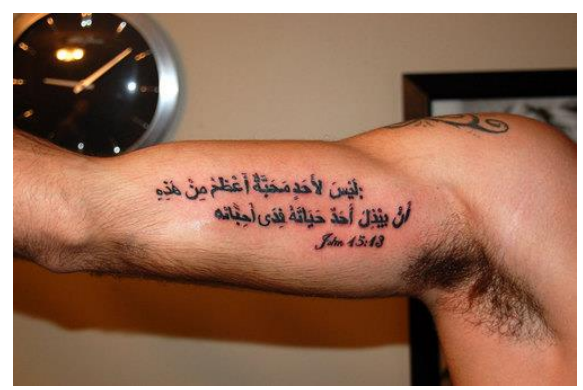

Gambar 11 - Sumber: https://www.arabamerica.com/12-terrible-arabic-tattoos-2/

Gambar (11) merupakan tato tulisan Arab yang ditatokan pada lengan seorang laki-laki. Tulisan tato Arab tersebut diambil dari Kitab Injil Yohanes 15:13 yang terbaca

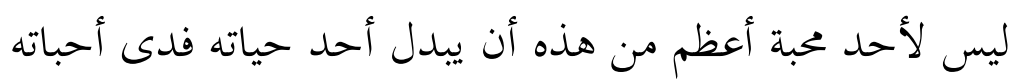

"Tidak ada kasih yang lebih besar dari pada kasih seorang yang memberikan nyawanya untuk sahabat-sahabatnya". ${ }^{41}$

41 “Yohanes 15:13 (Versi Paralel) - Tampilan Ayat - Alkitab Sabda," diakses 17 Mei 2019, http://alkitab.sabda.org/verse.php?book=Yoh\&chapter=15\&verse=13. 


\section{b. Fungsi Tulisan Tato Arab di Media Sosial}

Berdasarkan data yang telah dikumpulkan, fungsi tulisan tato Arab di media sosial secara sosiolinguistis adalah fungsi fatik, referensial, dan imajinatif.

\section{Fungsi Fatik}

Fungsi fatik tulisan tato Arab di media sosial adalah seperti pada gambar (12) berikut.

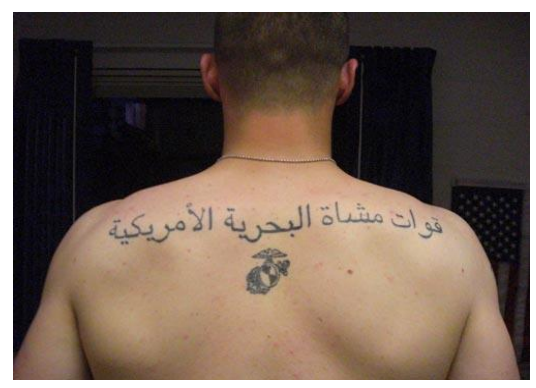

Gambar 12

Sumber: https://www.punditschool.net/artikel/15-gaya-dan-desain-huruf-huruf-tato-populer/

Dalam gambar (12) tampak seorang laki-laki yang menatokan tulisan Arab pada punggung bagian atas dengan tulisan arab yang berbunyi قوات مشاة البحرية الامريكية 'Korps Marinir Amerika Serikat'. Tulisan tato Arab tersebut secara sosiolinguistis mempunyai fungsi fatik, yaitu fungsi bahasa untuk menjalin dan memelihara hubungan, memperlihatkan perasaan persaudaraan atau solidaritas sesama anggota Korps Marinir Amerika Serikat.

\section{Fungsi Referensial}

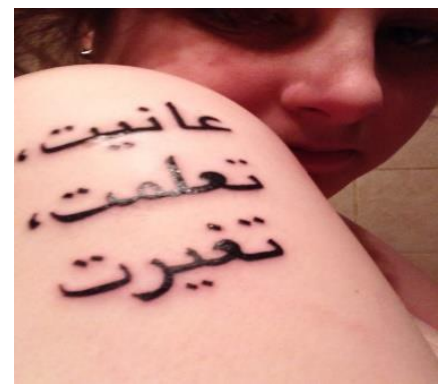

Gambar 13 - Sumber: https://www.gettattoosideas.com/arabic-tattoos/ 
Gambar (13) memperlihatkan seorang wanita yang menatokan tulisan Arab di lengan kanannya dengan tulisan عانيت، تعلمت، تغيرت 'anaitu, ta'allamtu, tagayyartu 'Aku niat, aku belajar, aku berubah'. Apabila dilihat dari topik ujarannya, tulisan tato Arab tersebut berfungsi referensial atau informatif, karena tulisan tato tersebut berfungsi sebagai alat untuk menginformasikan pandangan hidup penatonya. Fungsi ini menurut Crystal, sebagai fungsi untuk melahirkan atau menyatakan pikiran. ${ }^{42}$

\section{Fungsi Imajinatif}

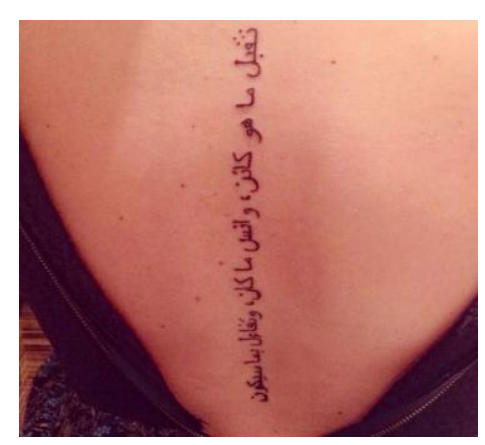

Gambar 14 - https://www.heytips.com/tatuajes-arabes-y-frases/

Pada gambar (14) memperlihatkan seorang wanita menatokan tulisan tato Arab di punggung bagian tengah dengan bahasa arab berbunyi تقبل ما هو كائن، وانس ما كان، وتفاءل بما سيكون Taqabbal ma huwa ka'in, wansa ma kana, wa tafa'ul bima sayakun 'Terimalah apa yang telah terjadi, lupakan apa yang telah terjadi, dan optimislah dengan apa yang akan terjadi’.

Gambar tersebut secara sosiolinguistis mempunyai fungi untuk menyatakan perasaan melalui kata-kata bijak atau disebut juga dengan fungsi imajinatif. Kata-kata bijak dalam kehidupan manusia merupakan penyemangat yang bisa membuat jiwa yang hancur dan

${ }^{42}$ Crystal, The Cambridge Encyclopedia of Language, h. 21. 
rapuh mulai bangkit lagi. Kata-kata bijak ibarat suatu asupan yang bisa membangkitkan diri dari kerterpurukan. ${ }^{43}$

Fungsi tulisan tato Arab yang mengandung kata-kata bijak ini adalah untuk memberikan sugesti dan motivasi kepada pembacanya yang kebetulan sedang menghadapi masalah agar tidak bersedih dan putus asa terhadap apa yang dialaminya. Di samping itu, diharapkan para pembacanya tetap optimis dalam menghadapi kehidupan di masa yang akan datang.

\section{Simpulan}

Berdasarkan penjelasan, keterangan, dan analisis yang telah dilakukan terhadap bentuk dan fungsi tulisan pada tato Arab di media sosial dapatlah diambil beberapa kesimpulan sebagai berikut.

Seni menggambar atau menuliskan tato Arab pada anggota tubuh merupakan fenomena kebahasaan yang mencerminkan ekspresi para pemakainya. Tulisan pada tato Arab di media sosial berbentuk kata, frasa, dan kalimat. Di samping itu, ditemukan juga tulisan pada tato Arab yang berupa rajah dan petikan ayat suci, baik dari ayat suci Alquran maupun Injil.

Tulisan pada tato Arab mempunyai fungsi sebagai bentuk ekspresi diri atau kelompok. Di samping itu, secara sosiolinguistis tulisan tato Arab di media sosial mempunyai fungsi fatik atau interpersonal/interaksional, referensial (representasional, kognitif, denotatif, informatif), dan imajinatif (poetic speech).

43 “1301 Kata Kata Bijak, Mutiara, Motivasi Singkat Cinta, Kehidupan, Lucu," 21 Juni 2018, https://moondoggiesmusic.com/kata-kata-bijak/. 


\section{DAFTAR PUSTAKA}

"1301 Kata Kata Bijak, Mutiara, Motivasi Singkat Cinta, Kehidupan, Lucu," 21 Juni 2018. https://moondoggiesmusic.com/kata-kata-bijak/.

Ad-Dahdah, Anton. A Dictionary of Arabic Grammar in Charts and Tables. Bairut: Maktabah Lubnan Nasyirun, 2001.

Al-Galayaini, Syaikh Mustafa. Jami'u ad-Durusi al-'Arabiyyati Mausu'atun Fi Salasati Ajza.' Bairut: Dar al-Hadis, 2005.

"Arti kata tato - Kamus Besar Bahasa Indonesia (KBBI) Online." Diakses 16 Mei 2019. https://kbbi.web.id/tato.

Chaer, Abdul. Sintaksis Bahasa Indonesia Pendekatan Proses. Jakarta: Rineka Cipta, 2009.

Chaer, Abdul, dan Leonie Agustina. Sosiolinguistik Pengenalan Awal. Jakarta: Rineka Cipta, 2004.

Crystal, David. The Cambridge Encyclopedia of Language. New York: Cambridge University Press, 1992.

"Curhat Angelina Jolie Soal Penyakit dan Perceraiannya | Republika Online." Diakses 17 Mei 2019.

https://www.republika.co.id/berita/\%20senggang\%20/blitz/17/07/27/otq 7r4328-curhat-angelina-jolie-soal-penyakit-dan-perceraiannya.

Gani, Abdul, dan Aiman Amin. Mulakhkhas Qawa'id al-Lugah al-'Arabiyyah. Kairo:

Dar at-Taufiq li at-Turas, 2012.

Hasanudin, W.S. Ensiklopedi Kebahasaan Indonesia. Bandung: Penerbit Angkasa, 2014.

“Mengapa Burung Merpati Jadi Simbol Perdamaian?” Diakses 17 Mei 2019.

http://www.apakabardunia.com/2013/01/mengapa-burung-merpati-jadisimbol.html.

“Mengenal Makna Dari Berbagai Simbol Agama.” Diakses 17 Mei 2019.

http://www.martinrecords.com/pengetahuan/mengenal-makna-dariberbagai-simbol-agama/.

"Meningkatkan Iman, Harapan dan Cinta Kepada Tuhan (Siraman Rohani, Senin 28/11/2016) - Mirifica News." Diakses 16 Mei 2019.

http://www.mirifica.net/2016/11/27/meningkatkan-iman-harapan-dancinta-kepada-tuhan-siraman-rohani-senin-28112016/.

Munawwir, A.W. Al-Munawwir: Kamus Arab-Indonesia. Surabaya: Pustaka Progressif, 2002.

"Pengertian Frasa, Ciri-ciri, Jenis Dan Contoh Frasa." Materi Belajar (blog). Diakses 16 Mei 2019. http://materi4belajar.blogspot.com/2016/02/pengertianfrasa-ciri-jenis-dan-contoh.html.

“Penjelasan Kalimat Verbal dan Kalimat Nominal." Diakses 17 Mei 2019. https://ketikakuberkata.blogspot.com/2018/01/penjelasan-kalimat-verbaldan-kalimat.html. 
“Rajah - Wiktionary bahasa Indonesia." Diakses 17 Mei 2019. https://id.wiktionary.org/wiki/rajah.

"Tato Temporer Justru Lebih Rentan Alergi." Diakses 16 Mei 2019. https://hot.detik.com/art/d-2401868/tato-temporer-justru-lebih-rentanalergi.

Wahbah, Majdi. Mu'jamu al-Mustalahat al-'Arabiyyah Fi al-Lugah wa al-Adab. Beirut: Maktabah Lubnan, 1984.

"Yohanes 15:13 (Versi Paralel) - Tampilan Ayat - Alkitab Sabda." Diakses 17 Mei 2019.

http://alkitab.sabda.org/verse.php?book=Yoh\&chapter=15\&verse=13. 